University for Business and Technology in Kosovo

UBT Knowledge Center

UBT International Conference

2015 UBT International Conference

Nov 7th, 9:00 AM - 5:00 PM

\title{
Planning, Development and Application of Mechatronics Systems as Students Work
}

\author{
Muzafer Shala \\ University for Business and Technology, muzafer.shala@ubt-uni.net \\ Valmir Hoxha \\ University for Business and Technology, valmir.hoxha@ubt-uni.net
}

Follow this and additional works at: https://knowledgecenter.ubt-uni.net/conference

Part of the Robotics Commons

\section{Recommended Citation}

Shala, Muzafer and Hoxha, Valmir, "Planning, Development and Application of Mechatronics Systems as Students Work" (2015). UBT International Conference. 43.

https://knowledgecenter.ubt-uni.net/conference/2015/all-events/43

This Event is brought to you for free and open access by the Publication and Journals at UBT Knowledge Center. It has been accepted for inclusion in UBT International Conference by an authorized administrator of UBT Knowledge Center. For more information, please contact knowledge.center@ubt-uni.net. 


\title{
Planning, Development and Application of Mechatronics Systems as Students Work
}

\author{
Muzafer Shala1, Valmir Hoxha1 \\ Faculty of Mechatronics Management, UBT, Prishtina, Kosovo \\ $\left\{\right.$ muzafer.shala $^{1}$, valmir.hoxha $\left.{ }^{1}\right\} @$ ubt-uni.net
}

\begin{abstract}
In Kosovo universities in general there is a lack of students practical work, this fact is one of the reasons why in Kosovo are no sufficient number of professionals to fill the market needs.

The aim of this work is to go through the steps of conceptualisation, development and application of a Mechatronics Sy stems with students. Also in this project students work on all the phases of the work which we consider to be of great benefit. The work was organised as it would be on a real life company, students were split on groups and the groups worked in different fields of project and also took part on every step taken during the development of project like the organisational and technical steps, for example: research, planning, development, programming, testing, deployment etc. This project was fully realised, tested and installed on site with students, its a opportunity and experience how the product development and realisation of a mechatronics systems and had great results on their future employment.
\end{abstract}

Keywords: Product Development, Industry, Students practical works, Testing, Deployment, Electronics, Sensors, PLC, Programming.

\section{Introduction}

In Kosovo there are great number of old machines of all sorts, some of them are inherited from the old factory's (after they got sold the machines were there) and this machines are at least $30 \mathrm{yrs}$. old, and another reason for great number of old machines in factory's in Kosovo is that they don't buy new machineries because of the cost they buy old used machines from region and Europe.

The mechanical parts of this old machines are almost the same as new counterparts because the technology in mechanical design did not have significant changes except the materials used, the most significant changes are made on the electronics, because of the rapid development of semiconductors and information technologies (IT), today there are different personal computer (PC) solution, embedded systems and also Programmable Logic Controllers (PLC) to be used as industry standard witch contributed on flexibility, data acquisition, shorter down time etc..

In Kosovo and region in general there is a lack of project based learning in universities, In this regard we took a packaging machine from a factory in Kosovo and together with the students realised all the phases of the project, Planing, Development, Testing and Deployment. [1]

The packaging machine was an analog controlled machine with the old mechanical weighing system, students had to redesign the electronics and the control using Programmable Logic Controllers (PLC) and also got rid of the old mechanical weighing system, replacing with the new weighing system using load cell sensors.

\section{Methodology}

Planning, during planning process students had to take in account this factors

- Investor requirements

The requests from the investor on how the machine should work

- Process requirements

The actual physical process, the capacity of machine, interventions needed etc.

- Infrastructure requirements

Working space (Mechatronics Lab of college UBT), tools and machines. 
- Budget requirements

- Bill of materials etc.

Development After the planning students went through the development process of:

- Electrical Parts

- Electronics Parts

- Mechanical Parts

- Software

Testing of the machine was made for:

- Individual Parts

- Testing the process through simulation

- Putting together all the parts and testing all together

Deployment and Commissioning The weighing machine was developed and tested in the mechatronics laboratory of College UBT, after deploying to the site, students had to make the commissioning and slight changes in the software to fully comply with the site requirements.

Development and Implementation

After planning students got to the development and implementation.

The development and implementation can be classified in four different parts.

Electronics

Electrical

Mechanical and

Software (Ladder Logic - PLC)

In the Figure 1. is shown the power and information flow of overall process.

The PLC is in the centre of this process, the sensors send feedback to the PLC, and the software will execute the logic and activate the outputs like: Vibrators and Solenoids

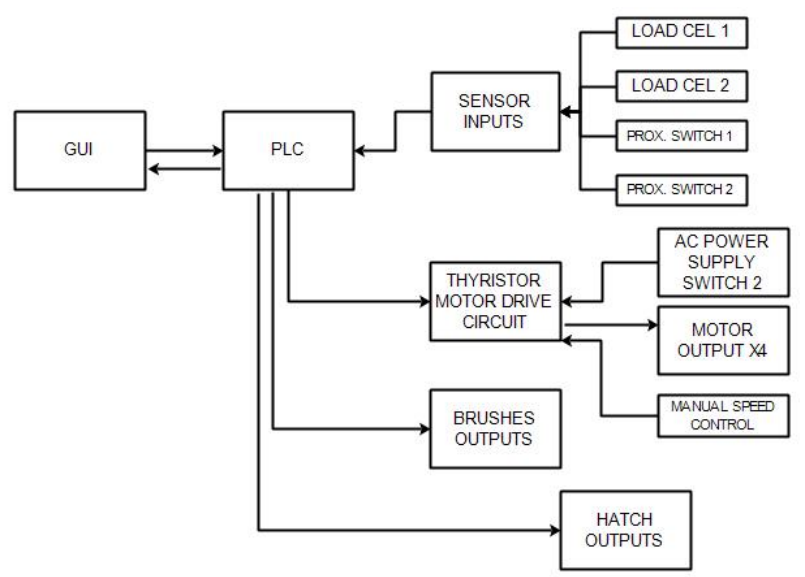

Figure 1 Development and Implementation

In GUI we can change parameters and see the values of weighing heads in real time.

Development Of Electronics

Students developed the Driver for Vibrators and the transmitter for Load Cell, in this case they learned the phase control with power electronics and signal processing with Operational Amplifiers. Software of PLC

The Students developed a software using ladder Logic to control the process of this packaging machine, they had great benefits in planning the software with the algorithm and realise it in Ladder Logic. It was a good experience on how a real life programming of Industrial machines is done.

Electrical Implementation 
In this part of process students worked on the wiring the electrical box, including the electronics that was developed from them, and also making the technical documentation of the electrical installation.[2]

\section{Difficulties encountered}

It was difficult to assure the owners of the machine to bring the machine in our lab. Because for us it is nearly impossible to work with the students in the factory in daily basis to conduct work. Bringing the machine to the UBT Machatronics Lab, was quite important and worthy for our students to see and participate in this process.

Another difficulty because of the installations carried out from the student with no prior experience, in putting the things together and working as a team, all of which we got through and gained experience. [3]

\section{Results}

The results of the weighing accuracy was very high, and it was possible that by adjusting different parameters to get better results in accuracy, in the best case we got $95 \%$ of the packages were within the allowed tolerance of $6 \%$ and in the worst case $80 \%$.

The weighing accuracy of the weighing heads depends on many factors.

The speed of the feeders, the higher the speed the lower the accuracy, and also the parameters of course and fine dosing of feeders, the closer the course value to the packaging value the lower the accuracy.

Here are some of the results obtained from the testings done in the plant.

The speed of dosing feeders was constant on every measurement

Fine dosing feeders speed set to 6 out of 10 .

Coarse dosing feeder speed set to 4 out of 10 .

By changing the coarse feeder parameter we got this results for the $600 \mathrm{gr}$ packages.

As you can see from the Figure 2. the best results obtained when the coarse feeder parameter was set to $550 \mathrm{gr}$ the result

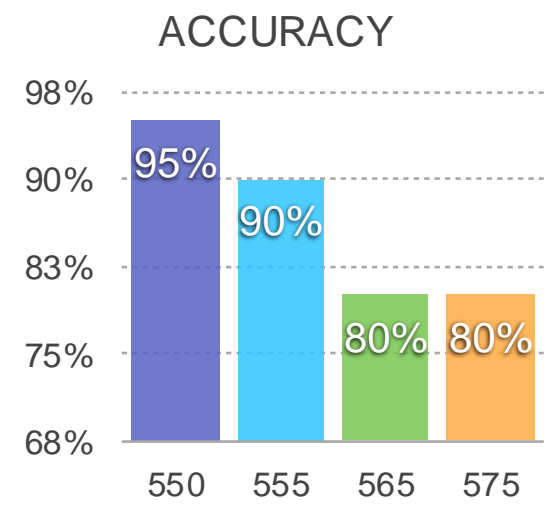

Figure 2 Accuracy dependancy on the coarse feeder parameter.

is $95 \%$ accuracy and the worst result was obtained when the coarse feeder parameter was set to $575 \mathrm{gr}$ in this case we obtained $80 \%$ accuracy.

Also the return of the investments was calculated where the estimated return of investment is less than 3 months, taking in account the capacity of packaging that needs to be covered from the manual weighing of the labour force.

The weighing machine has a capacity of 3446 packages $/ \mathrm{shift}$ or $2067 \mathrm{~kg} / \mathrm{shift}$, shift is calculated as 8 hours of work. 


\section{Conclusions}

This Practically applied project which is done from UBT students and staff to solve problems in industry, implement new production digital line systems and bring to our students opportunities to gain knowledge in Learning-by-Doing model, has positive impact to innovation in less developed regions. Also this process will bring some more opportunities for students to do the internship and get employment in companies.

\section{References}

1. Kopacek, P., Shala, M., Ismaili, K., Sylaj, F., Research and Education with Scrap, 15th Workshop on International Stability, Technology, and Culture, IFAC, June 6-8, 2013. Prishtina, Kosovo

2. D. Alciatore and M. Histand, Introduction to Mechatronics and Measurement Systems, 2012: McGraw-Hill Companies, inc., New York.

3. Hajrizi, E., Shala, M., Hoxha, V., Stapelton, L., Cost-Oriented Agile Innovation for Mechatronics Management in Less Developed Regions, 16th 16th IFAC Conference on Technology, Culture and International Stability TECIS 2015 Sozopol, Bulgaria, 24-27 September 2015. Sozopol, Bulgaria 